\title{
Seedling density according to structure, dominance and understory cover in old-growth forest stands of the evergreen forest type in the coastal range of Chile
}

\author{
Densidad de plántulas de acuerdo a la estructura, dominancia y cobertura del sotobosque \\ en bosques siempreverdes adultos en la cordillera de la Costa de Chile
}

\author{
PABLO J. DONOSO ${ }^{1} \&$ RALPH D. NYLAND**
}

${ }^{1}$ Instituto de Silvicultura, Universidad Austral de Chile, Casilla 567, Valdivia, Chile; e-mail: pdonoso@uach.cl

${ }^{2}$ College of Environmental Science and Forestry, State University of New York, One Forestry Drive,

Syracuse, NY 13210, USA; e-mail: rnyland@mailbox.syr.edu

\begin{abstract}
Securing timely regeneration is essential in maintaining the long-term ecological or silvicultural functions and values of forests. Its establishment, in turn, depends on many factors, including the structure and composition of the forest itself. Available information shows that seedling density varies greatly across the evergreen forest type in Chile. Yet stand variables that may affect the establishment of advance regeneration have not been studied. To that end, we evaluated seven stands of the coastal range, within the northern part of the evergreen forest type $\left(39^{\circ} 14^{\prime}-40^{\circ} 16^{\prime} \mathrm{S}\right)$. We documented understory cover, tree density and dominance, and stand structure, and used the information to assess their effects over seedling density. Findings indicate that Laurelia philippiana was the dominant canopy and regenerating species in these stands. Also, seedling density was significantly greater in stands at lower elevations where shade-tolerant Aextoxicon punctatum was important. Chusquea spp. and Lophosoria quadripinnata, both understory species, had a significant negative effect on seedling density. Basal area and canopy cover, per se, showed little relationship with seedling density. Vertical structure, evaluated through a crown index, had a significant relationship with seedling density, but the direction depended on the species (e.g., L. philippiana and A. punctatum) and the diameter structure within our plots. Fitted models that included these variables were highly significant, and in most cases their significance increased considerably (14 to $26 \%$ ) when we accounted for the diameter structures of the plots.
\end{abstract}

Key words: Laurelia philippiana, Aextoxicon punctatum, old-growth forests, vertical structure, Chusquea spp.

\section{RESUMEN}

La regeneración es esencial para mantener en el largo plazo las funciones y valores ecológicos o silviculturales de los bosques. Su establecimiento depende de varios factores, incluyendo la estructura y composición del bosque. La información disponible indica que existe una gran variabilidad en la densidad de plántulas a través de la distribución del tipo forestal siempreverde en Chile. Sin embargo, las variables de rodal que puedan afectar el establecimiento de regeneración avanzada no se han estudiado. En este estudio se evaluaron siete rodales de la cordillera de la Costa, en la parte norte de la distribución del tipo forestal $\left(39^{\circ} 14^{\prime}-40^{\circ} 16^{\prime} \mathrm{S}\right)$. En ellos se midió la densidad de árboles, plántulas y brinzales, y se estimó la cobertura de copas de los árboles así como del sotobosque, con la finalidad de evaluar los efectos de la dominancia, la estructura y la cobertura del sotobosque sobre la densidad de plántulas de especies forestales. Laurelia philippiana fue la especie dominante a nivel arbóreo y de plántulas. El número de plántulas fue en general significativamente más abundante a altitudes menores donde Aextoxicon punctatum fue importante. Chusquea spp. y Lophosoria quadripinnata, ambas especies del sotobosque, tuvieron un efecto negativo significativo en la densidad de plántulas. El área basal y la cobertura de copas mostraron una pobre relación con la densidad de plántulas. La estructura vertical, evaluada a través del índice de copas, tuvo una relación significativa con la densidad de plántulas, pero su dirección dependió de la especie (i.e., L. philippiana y A. punctatum) y la estructura de diámetros de las parcelas. Los modelos ajustados con estas variables fueron altamente significativos, y en la mayoría de los casos su significancia aumentó considerablemente (14 a $26 \%$ ) cuando se ajustaron separadamente para parcelas con distintas estructuras diamétricas.

Palabras clave: Laurelia philippiana, Aextoxicon punctatum, bosques antiguos, estructura vertical, Chusquea spp. 


\section{INTRODUCTION}

Forest regeneration is the key process that ensures successive generations of trees (Barnes et al. 1998), and a primary requirement for maintaining the ecological or silvicultural functions of a forest. Yet tree seedling establishment depends on many biophysical factors, including the structure and composition of a stand (Crow \& Metzger 1987, Nyland 2002), the abundance and distribution of canopy gaps (Veblen 1992, and references therein), and the presence of microsites suited to tree seedling establishment (Lusk 1995, Szewczyk \& Szwagrzyk 1996, Chistie \& Armesto 2003). Within old-growth forests, tree seedling density also seems related to the availability of propagules of species that can grow in shade or beneath small canopy openings (sensu Oliver \& Larson 1996), such as species adapted to the continuous and gapphase regeneration modes (Veblen 1992). In these forest stands, seedling establishment varies with the degree of shade cast by larger trees (e.g., Leak \& Graber 1976, Crow \& Metzger 1987, Clark et al. 1999), and by understory species that might oppress tree seedling development by reducing light availability near the ground. In forests with great vertical structure diversity, light levels in the understory are relatively higher than beneath stands with a poorer vertical stratification (Brown \& Parker 1994,Van Pelt \& Franklin 2000), and this may result in greater understory tree density in areas outside canopy gaps (Van Pelt \& Franklin 2000).

In the evergreen (Valdivian) forest type of Chile, several studies have assessed seedling densities in late-successional and old-growth forests, showing dramatic differences in numbers among stands. On the Chiloé Island, for instance, an old-growth forest dominated by Eucryphia cordifolia and Laurelia philippiana (Donoso et al. 1985) had from 10,000 to 25,000 seedlings $(<2 \mathrm{~m}$ tall $) \mathrm{ha}^{-1}$, with Myrtaceae species accounting for $>70 \%$ of them. Stands dominated by Drimys winteri associated with Nothofagus nitida and conifers of the Podocarpaceae family had from 38,000 to 76,000 seedlings (< $1.3 \mathrm{~m}$ tall) $\mathrm{ha}^{-1}$, mostly belonging to Amomyrtus luma and Podocarpus nubigena (Aravena et al. 2002). By contrast, stands dominated by L. philippiana and
Myrtaceae species had only 837 seedlings and saplings ha-1 (Armesto \& Fuentes 1988). Within the coastal range, Donoso (1989) reported that tree seedling densities averaged $318,000\left(<2 \mathrm{~m}^{2}\right.$ tall $) \mathrm{ha}^{-1}$ for old-growth stands (mostly E. cordifolia, D. winteri, Podocarpaceae species, and L. philippiana). He counted 1,697 thousand tree seedlings $(<2 \mathrm{~m}$ tall) $\mathrm{ha}^{-1}$ (mostly Amomyrtus luma, $L$. philippiana and D. winteri) in stands of the Andes.

Aside from these general findings, research has not clearly identified the stand variables that affect the characteristics of advance regeneration within mature and old-growth forest stands of the evergreen forest type. To address this question, we sampled seven stands ( $>250$ yrs old each) along the coastal range in the Province of Valdivia. We sought to describe differences in abundance and composition of regeneration with reference to overstory and understory characteristics. We hypothesized that tree seedling density would be lower in stands having greater understory and overstory cover, and more abundant in stands having a high degree of vertical structural complexity.

\section{STUDY AREA AND STAND CHARACTERISTICS}

Sample stands were located in the Provinces of Valdivia and Cautín, along the Coastal Range and its extension to the Central Depression of Chile, between $39^{\circ} 14^{\prime}$ and $40^{\circ} 16^{\prime} \mathrm{S}$ (Table 1). This region has a temperate maritime climate with high annual precipitation, and an average annual temperature of $11-12{ }^{\circ} \mathrm{C}$ over the last 37 yr (Pezoa 2003). It is within a broader macroclimatic region lacking a dry period (Schlatter et al. 1995), except for the stand at Los Boldos on the western slope (Table 1). That area has one dry month per year (Schlatter et al. 1997). Soils on the eastern side of the Coastal Range (Table 1) have old volcanic ash deposited over the mica-schist metamorphic bedrock, are deep $(>60 \mathrm{~cm})$, and have moderate to good drainage. The western side of the coastal range (Table 1) has soils developed in situ over the mica-schist bedrock. These have poor drainage, are shallow $(<46 \mathrm{~cm})$ (Schlatter et al. 1995, Schlatter et al. 1997), more acidic, and have a higher bulk density (CIREN 1999). 
TABLE 1

General locations of the seven stands studied in evergreen forests of Chile

Ubicación general de los siete rodales estudiados en bosques siempreverdes

\begin{tabular}{lcccccc}
\hline Stand & $\begin{array}{c}\text { Latitude } \\
\text { (South) }\end{array}$ & $\begin{array}{c}\text { Longitude } \\
\text { (West) }\end{array}$ & $\begin{array}{c}\text { Elevation } \\
(\mathrm{m})\end{array}$ & Aspect & $\begin{array}{c}\text { Slope } \\
\text { range }(\%)\end{array}$ & Location \\
\hline Los Boldos (LB, cut 1992) & $39^{\circ} 14^{\prime} 36^{\prime \prime}$ & $73^{\circ} 00^{\prime} 19^{\prime \prime}$ & 500 & $\mathrm{~S} / \mathrm{SE}$ & $3-20$ & Western side of coastal range \\
Llancahue (LL) & $39^{\circ} 50^{\prime} 20^{\prime \prime}$ & $73^{\circ} 07^{\prime} 18^{\prime}$ & 330 & $\mathrm{~S} / \mathrm{SW}$ & $5-18$ & Eastern side of coastal range \\
La Montaña (LM, cut 1993) & $39^{\circ} 57^{\prime} 00^{\prime \prime}$ & $72^{\circ} 41^{\prime} 15^{\prime}$ & 330 & $\mathrm{SW} / \mathrm{E}$ & $3-25$ & Eastern side of coastal range \\
Hueicolla Uncut (HU) & $40^{\circ} 10^{\prime} 13^{\prime \prime}$ & $73^{\circ} 33^{\prime} 02^{\prime \prime}$ & 540 & $\mathrm{~S} / \mathrm{SE} / \mathrm{N}$ & $5-18$ & Western side of coastal range \\
Hueicolla Cut (HC, cut 1983) & $40^{\circ} 10^{\prime} 13^{\prime \prime}$ & $73^{\circ} 33^{\prime} 02^{\prime \prime}$ & 540 & $\mathrm{~N} / \mathrm{SW}$ & $10-34$ & Western side of coastal range \\
Llancacura Uncut (LU) & $40^{\circ} 16^{\prime} 36^{\prime \prime}$ & $73^{\circ} 23^{\prime} 48^{\prime \prime}$ & 630 & $\mathrm{~S} / \mathrm{SE}$ & $5-18$ & Eastern side of coastal range \\
Llancacura Cut (LC, cut 1994) & $40^{\circ} 16^{\prime} 36^{\prime \prime}$ & $73^{\circ} 23^{\prime} 48^{\prime}$ & 630 & $\mathrm{~S}$ & $6-15$ & Eastern side of coastal range
\end{tabular}

We located four stands on the eastern side of the Coastal Range (two at $330 \mathrm{~m}$, and two at $630 \mathrm{~m}$ elevation), and three along the western side (at 500-540 m). Each covered at least 3 ha, with original basal areas ranging from 71 to $111 \mathrm{~m}^{2} \mathrm{ha}^{-1}$. Of the seven stands, three had been selectively cut 5-7 yr earlier. In another stand, groups of trees were removed $16 \mathrm{yr}$ earlier, with no cutting between the groups (Donoso 1989). Three stands had no cutting history (Table 1). All together, the partial cuttings removed 16 to $26 \%$ of the basal area, and about $10 \%$ of the trees, leaving an average stocking of 64 to $98 \mathrm{~m}^{2} \mathrm{ha}^{-1}$. The quadratic stand diameters (QSD, diameter of the tree of mean basal area) ranged from 33.6 to $47.1 \mathrm{~cm}$.

None of the cuttings affected the overall composition or the diameter and vertical structures of the stands (Donoso 2002). They were characterized by an upper canopy layer of E. cordifolia and Weinmannia trichosperma, a subcanopy layer dominated by L. philippiana, and an understory of Myrtaceae species with scattered Raphythamnus spinosum and Lomatia ferruginea. The Llancacura stands also had an emergent layer of scattered Nothofagus dombeyi trees. At La Montaña, Aextoxicon punctatum shared all diameter classes with $L$. philippiana. In stands on the western slopes, Podocarpaceae species (particularly Saxegothaea conspicua) where abundant (Donoso 2002). Overall, the stands correspond to the evergreen-with-shade-intolerantemergents forest subtype as defined by Donoso (1981).

\section{MATERIAL AND METHODS}

Seedlings, saplings, and undergrowth

In each stand, we systematically located five to six square $1,000 \mathrm{~m}^{2}$ plots, each separated by $50 \mathrm{~m}$. In these plots we measured the diameter at breast height $(\mathrm{dbh})$ of all trees $\geq$ $5 \mathrm{~cm}$. Each plot was then subdivided into four equal $250 \mathrm{~m}^{2}$ squares, each having four $2-\mathrm{m}^{2}$ circular subplots located at $7.45 \mathrm{~m}$ from the corners. This provided a total of 16 subplots $\left(32 \mathrm{~m}^{2}\right)$ in each $1,000 \mathrm{~m}^{2}$ plot. In the subplots, tree seedlings were recorded by height class $(5-<50 \mathrm{~cm}, 50-<100 \mathrm{~cm}$, and $100-200 \mathrm{~cm})$ and species. The cover (\%) of herbs, shrubs, and ferns was also estimated by four height classes $(<50 \mathrm{~cm}, 50-<100$ $\mathrm{cm}, 100-<200 \mathrm{~cm}$, and $\geq 200 \mathrm{~cm}$ ). Seedlings $<5 \mathrm{~cm}$ tall were not tallied because most of them are ephemeral. Saplings (trees $<5 \mathrm{~cm}$ $\mathrm{dbh}$ and taller than $2 \mathrm{~m}$ ) were also counted in the $2 \mathrm{~m}^{2}$ subplots. This systematic sampling allowed us to estimate seedling abundance over average microsite conditions, without bias towards any particular set of conditions within the stands.

\section{Overstory variables}

Among overstory variables that could potentially affect regeneration, we evaluated basal area, canopy cover, and vertical structure. Although small gaps were observed in portions of the sample stands, the high average basal areas (50 to $90 \mathrm{~m}^{2} \mathrm{ha}^{-1}$ ) indicate that the plots 
themselves lacked upper-canopy gaps of any appreciable size.

To estimate the actual canopy cover, we measured the dbh and canopy area of all trees $\geq$ $5 \mathrm{~cm} \mathrm{dbh}$ in one $250 \mathrm{~m}^{2}$ subplot within each $1,000 \mathrm{~m}^{2}$ plot. The widest crown diameter and the one perpendicular to it were recorded for each of these trees. From these measurements, we modelled the relationship between $\mathrm{dbh}$ and crown area (based on an ellipse) (Donoso 2002), and used the models to calculate canopy cover across the plots.

To analyze vertical structure, we assigned each plot to a specific structure class based on a modification of the Triangle of Structures (Fig. 1) developed by the French Society of FrancheComté for irregular (multistrata) forests (SFFC 2000). Their classification recognizes seven possible structures, depending on the proportion of trees in small $(10-25 \mathrm{~cm} \mathrm{dbh})$, medium $(>25-50 \mathrm{~cm} \mathrm{dbh})$, and large $(>50 \mathrm{~cm}$ dbh) dbh classes, as follows: $\mathrm{S}=$ stand or plot dominated by small trees; $\mathrm{SM}=$ stand or plot dominated by a mixture of small and medium trees; $\mathrm{SL}=$ stand or plot dominated by a mixture of small and large trees; $\mathrm{M}=$ stand or plot dominated by medium trees; $\mathrm{L}=$ stand or plot dominated by large trees; $\mathrm{ML}=$ stand or plot dominated by a mixture of medium and large trees; IR = stand or plot dominated by a mixture of small, medium, and large trees. Vertical structure was also represented by a Crown Index (CI) (Donoso 2002), based on canopy cover for four broad classes of trees: upper main canopy (UMC; $>50 \mathrm{~cm}$ ), lower main canopy (LMC; 30-50 cm), below main canopy (BMC; 15-<30 cm), and overtopped $(\mathrm{OT} ;<15 \mathrm{~cm})$. We calculated $\mathrm{CI}$ as:

\section{$\mathrm{CI}=(\mathrm{UMC} / \mathrm{UMC}+\mathrm{UMC} / \mathrm{LMC}+$ $\mathrm{UMC} / \mathrm{BMC}+\mathrm{UMC} / \mathrm{OT}) / 4$}

Values close to 1.0 indicate a balance in the distribution of crown area among the different tree size classes. Values greater than 1.0 reflect a disproportionate crown area among large trees. A CI of $<1.0$ identifies stands with higher concentrations of crown area in small trees.

\section{Analyses}

Cover of understory species, and seedling and sapling density by species, was compared among the stands. Data for canopy and noncanopy species were analyzed separately. Variation in seedling density was also compared between plots with different structures: plots where small trees were dominant (S) or codominant (SM and SL) were analysed separately from plots with a more balanced mixture of tree sizes (IR) (see Fig. 1). Tree dominance was evaluated through basal area and canopy cover. Understory variables considered were the overall cover of Lophosoria quadripinnata and Chusquea spp., and the cover of these two species in the tallest height classes (> $50 \mathrm{~cm}$ for L. quadripinnata, and $>200 \mathrm{~cm}$ for Chusquea spp.).

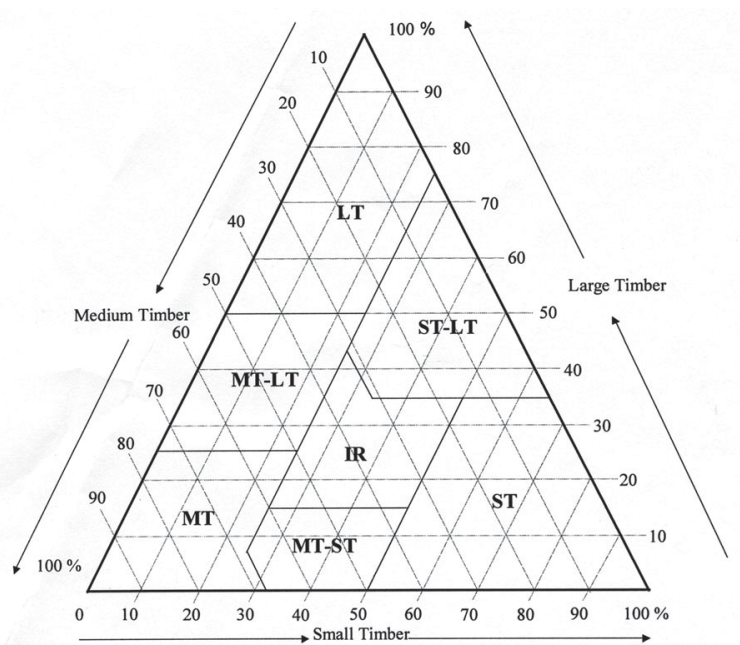

Fig.1: Triangle of structures for irregular forests from the Society of Foresters of the French-Comté in France (SFFC 2000) for classification of irregular forests into one of seven possible diameter structures (see text): $\mathrm{T}=\mathrm{tim}-$ ber; $\mathrm{S}=$ small; $\mathrm{M}=$ medium; $\mathrm{L}=$ large; $\mathrm{IR}=$ irregular.

Triángulo de estructuras para bosques irregulares de la Sociedad de Forestales de French-Comté en Francia (SFFC 2000) para la clasificación de bosques irregulares en una de siete posibles estructuras diamétricas (ver texto): $\mathrm{T}=$ timber (Madera); $\mathrm{S}=$ small (pequeña); $\mathrm{M}=$ medium (mediana); $\mathrm{L}=$ large (grande); $\mathrm{IR}=$ irregular (irregular).

We used SAS statistical package (SAS 2001) for all statistical analyses. Model development was conducted using the stepwise procedure, after checking the data for normality and homocedasticity. Regression models with the lowest mean square errors, lowest P-values, and highest coefficient of determinations $\left(\mathrm{R}^{2}\right)$ 
were selected. Transformations were conducted when necessary to improve the models. Possible collinearity between regressor variables were addressed with the COLLIN option in SAS. Individual independent variables were kept in the regression analysis when significant at $\alpha \leq 0.05$ and were not collinear with other variables in the model. Analysis of variance and means separation by the least square difference (LSD) test ( $\alpha=$ $0.05)$ were used to compare seedling densities among stands.

\section{RESULTS}

\section{Differences in species composition}

Twenty-two species of trees ( $\geq 5 \mathrm{~cm} \mathrm{dbh}$ ) were sampled across the seven sites. Stands on the eastern slopes had between 10 and 12 tree species each, while those in the west had from 12 to 16 per stand (Table 2). However, in all stands only two or three species dominated, as reflected by their importance values (IV) (Table 2; Cottam \& Curtis 1956, Donoso 1993).

TABLE 2

Importance values ${ }^{\mathrm{a}}$ for species that reached $\mathrm{a} d \mathrm{dbh} \geq 5 \mathrm{~cm}$ in each sampled stand (species with a nominal IV: present species: p; absent species: a)

Valor de importancia ${ }^{a}$ para las especies que alcanzan un dap $\geq 5 \mathrm{~cm}$ en cada rodal muestreado (especies con un IV nominal: presente: p; ausente: a)

\begin{tabular}{|c|c|c|c|c|c|c|c|}
\hline \multirow[b]{2}{*}{ Species } & \multicolumn{7}{|c|}{ Stand ${ }^{b}$} \\
\hline & LL & $\mathrm{LU}$ & $\mathrm{LC}$ & LM & LB & $\mathrm{HU}$ & $\mathrm{HC}$ \\
\hline Laurelia philippiana & 37.6 & 43.6 & 24.0 & 50.3 & 23.9 & 29.0 & 29.7 \\
\hline Eucryphia cordifolia & 33.6 & 12.1 & 27.5 & 6.1 & 10.2 & 12.8 & 10.8 \\
\hline Amomyrtus luma/Amomyrtus meli/Myrceugenia planipes & 10.2 & 10.1 & 10.7 & a & 3.4 & 21.7 & 20.0 \\
\hline Aextoxicon punctatum & 6.7 & $\mathrm{a}$ & $\mathrm{a}$ & 32.9 & 9.0 & 8.3 & 4.8 \\
\hline Dasyphyllum diacanthoides & 1.5 & 7.8 & 4.1 & $\mathrm{a}$ & 0.1 & 9.8 & 5.0 \\
\hline Saxegothaea conspicua & $\mathrm{a}$ & $\mathrm{a}$ & $\mathrm{a}$ & a & 7.3 & 4.3 & 14.0 \\
\hline Podocarpus nubigena & a & $\mathrm{a}$ & $\mathrm{a}$ & a & 2.8 & 0.6 & 0.8 \\
\hline Nothofagus dombeyi & a & 15.0 & 18.8 & a & a & $\mathrm{a}$ & $\mathrm{a}$ \\
\hline Weinmannia trichosperma & 5.1 & 9.3 & 13.8 & $\mathrm{a}$ & 28.8 & 6.2 & $\mathrm{a}$ \\
\hline Gevuina avellana & 0.0 & $\mathrm{a}$ & $\mathrm{a}$ & 3.0 & 6.8 & 1.9 & 4.1 \\
\hline Drimys winteri & 2.7 & a & a & A & 1.9 & 1.6 & 3.9 \\
\hline Laurelia sempervirens & a & a & a & 3.2 & $\mathrm{a}$ & a & $\mathrm{a}$ \\
\hline Persea lingue & a & a & a & 1.77 & 0.13 & a & a \\
\hline Nothofagus obliqua & a & a & a & 0.37 & a & a & a \\
\hline Podocarpus salignus & a & a & a & A & $\mathrm{p}$ & a & a \\
\hline Raphythamnus spinosum & $\mathrm{p}$ & $\mathrm{p}$ & $\mathrm{p}$ & $\mathrm{P}$ & $\mathrm{p}$ & $\mathrm{p}$ & $\mathrm{p}$ \\
\hline Lomatia ferruginea & $\mathrm{p}$ & $\mathrm{p}$ & $\mathrm{p}$ & $\mathrm{P}$ & $\mathrm{p}$ & $\mathrm{p}$ & $\mathrm{p}$ \\
\hline Pseudopanax laetevirens & a & $\mathrm{p}$ & a & A & a & $\mathrm{p}$ & $\mathrm{p}$ \\
\hline Azara lanceolata & a & a & a & A & a & $\mathrm{p}$ & a \\
\hline Aristotelia chilensis & a & a & a & $\mathrm{P}$ & a & a & a \\
\hline Lomatia dentata & $\mathrm{p}$ & a & a & $\mathrm{P}$ & a & a & a \\
\hline Caldcluvia paniculata & a & a & a & A & $\mathrm{p}$ & $\mathrm{p}$ & a \\
\hline Total number of tree species & 11 & 10 & 10 & 12 & 15 & 16 & 12 \\
\hline
\end{tabular}

(a) Importance value: (relative density + relative basal area)/2; (Cottam \& Curtis 1956, Donoso 1993);

(b) $\mathrm{LL}=$ Llancahue; LU = Llancacura Uncut; LC = Llancacura Cut; LM = La Montana; HU = Hueicolla Uncut; HC = Hueicolla Cut; LB = Los Boldos 
We identified more than 60 species in the understory of the seven stands (Donoso 2002). Only 10 species were common to all stands, or had a relatively high cover in at least some stands (Table 3). Chusquea spp. (a bamboo) had the highest cover in all stands except for Llancacura Uncut and Llancacura Cut. There $L$. quadripinnata, a 1 to $2 \mathrm{~m}$ tall fern, had the highest cover. Chusquea spp. accounted for > $42 \%$ cover at Hueicolla, $30 \%$ at Los Boldos, $12 \%$ at La Montaña, and $<5 \%$ at Llancahue and the Llancacura stands. Other species with relatively high cover in most stands were Luzuriaga spp., Nertera granadensis, and the vine Mitraria coccinea (Table 3).

Llancahue had the least understory cover $(12.6 \%)$ and the lowest average cover in each of the three height categories. Llancacura Uncut had $20 \%$, and Llancacura Cut $25 \%$ cover. The two cut stands on the western slope (Hueicolla Cut and Los Boldos) had the highest covers (64 and $63 \%$ ). Hueicolla Uncut and La Montaña had 52 and $53 \%$ cover (Table 3). For the two tallest understory height classes, Hueicolla Cut had $56 \%$ cover, Hueicolla Uncut $43 \%$, and Los Boldos $31 \%$ cover. La Montaña and Llancacura Cut ranked intermediate (14.8
$\%$ and $15.6 \%)$, and Llancacura Uncut (10.2\%) and Llancahue $(5.6 \%)$ had the lowest covers. The relatively high tall understory cover along the western slope was due to Chusquea spp.

\section{Seedling density of canopy species}

Stands on the eastern slope had more seedlings. In all stands, the $5-<50 \mathrm{~cm}$ height class had the greatest numbers of seedlings per ha (Table 4), and we could distinguish three groups of stands based on stocking in this seedling height class: (1) La Montaña, with 24,583 seedlings ha-1 and significantly different from all other stands; (2) Llancahue, Llancacura Uncut, Llancacura Cut, and Los Boldos, with 13,332 seedlings ha-1 at Llancahue and 6,000-9,000 seedlings $\mathrm{ha}^{-1}$ beneath the other stands; and (3) Hueicolla Cut and Hueicolla Uncut, with the fewest seedlings (3,500 and 1,668 seedlings ha ${ }^{-1}$, respectively).

For the $50-<100 \mathrm{~cm}$ class, Llancahue, La Montaña, and Llancacura Uncut had > 3,000 seedlings $\mathrm{ha}^{-1}$. Those stands differed significantly from Hueicolla Uncut (968 seedlings ha-1). Llancacura Cut, Hueicolla Cut, and Los Boldos ranked intermediate $(1,200$ to 2,300 seedlings $\left.\mathrm{ha}^{-1}\right)$. For seedlings $100-<200$

TABLE 3

Mean cover ${ }^{\mathrm{a}}$ and standard errors for main understory vascular non-tree species in the five or six plots sampled in each stand

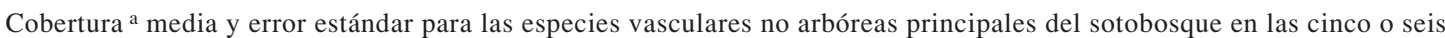
parcelas muestreadas en cada rodal

\begin{tabular}{lccccccc}
\hline \multirow{2}{*}{ Species } & \multicolumn{7}{c}{ Stand $^{\text {b }}$} \\
\cline { 2 - 8 } & LL & LU & LC & LM & LB & HU & HC \\
\hline Chusquea macrostachya/C. quila & $3.5 \pm 0.4$ & $0.3 \pm 0.1$ & $4.9 \pm 1.1$ & $12.2 \pm 2.0$ & $29.6 \pm 4.1$ & $42.4 \pm 2.1$ & $42.5 \pm 2.2$ \\
Lophosoria quadripinnata & $2.4 \pm 0.4$ & $4.1 \pm 0.7$ & $8.3 \pm 1.0$ & $0.7 \pm 0.3$ & $5.2 \pm 1.1$ & $1.1 \pm 0.2$ & $8.5 \pm 0.8$ \\
Luzuriaga radicans/L. erecta & $1.4 \pm 0.1$ & $1.8 \pm 0.1$ & $3.3 \pm 0.2$ & $11.4 \pm 1.5$ & $4.0 \pm 0.4$ & $1.8 \pm 0.01$ & $1.7 \pm 0.13$ \\
Lapageria rosea & $0.7 \pm 0.1$ & $0.0 \pm 0.0$ & $0.1 \pm 0.1$ & $1.5 \pm 0.2$ & $2.5 \pm 0.3$ & $1.6 \pm 0.3$ & $2.4 \pm 0.1$ \\
Mitraria coccinea & $0.4 \pm 0.04$ & $4.6 \pm 0.7$ & $2.2 \pm 0.3$ & $1.8 \pm 0.3$ & $1.8 \pm 0.1$ & $0.9 \pm 0.1$ & $2.9 \pm 0.5$ \\
Nertera granadiensis & $0.9 \pm 0.2$ & $2.1 \pm 0.5$ & $1.1 \pm 0.3$ & $2.3 \pm 0.7$ & $17.0 \pm 1.7$ & $0.2 \pm 0.1$ & $0.04 \pm 0.01$ \\
Greigia sphaceolata & $0.02 \pm 0.01$ & $0.2 \pm 0.07$ & $0.2 \pm 0.07$ & $0.3 \pm 0.06$ & $0.02 \pm 0.01$ & $0.43 \pm 0.09$ & $1.8 \pm 0.25$ \\
Hydrangea integerrima & $0.03 \pm 0.01$ & $0.0 \pm 0.0$ & $0.0 \pm 0.0$ & $0.0 \pm 0.0$ & $0.1 \pm 0.03$ & $1.0 \pm 0.01$ & $0.03 \pm 0.01$ \\
Total cover & $12.6 \pm 0.5$ & $20.1 \pm 1.0$ & $25.1 \pm 2.2$ & $51.7 \pm 4.1$ & $64.1 \pm 5.5$ & $53.3 \pm 1.8$ & $62.5 \pm 1.5$ \\
All non-tree species & 32 & 24 & 25 & 36 & 21 & 23 & 18 \\
\hline
\end{tabular}

(a) Cover is percent ground area occupied by the projection of a species' above-ground biomass;

(b) $\mathrm{LL}=$ Llancahue; LU = Llancacura Uncut; LC = Llancacura Cut; LM = La Montana; LB = Los Boldos; HU = Hueicolla Uncut; $\mathrm{HC}=$ Hueicolla Cut 
cm tall, La Montaña, Llancacura Uncut, and Llancahue had $>3,000$ seedlings $\mathrm{ha}^{-1}$, and Hueicolla Uncut had the fewest (563 seedlings $\mathrm{ha}^{-1}$ ). The remaining stands had from 1,438 to 2,396 seedlings ha ${ }^{-1}$ in this height class.

Considering all height classes, La Montaña had significantly more seedlings than the other stands. Llancahue ranked second, and although it had $>20$ thousand seedlings/ha, it did not differ significantly from the Llancacura stands that had 14,479 (Cut) and 12,708 (Uncut) seedlings ha ${ }^{-1}$. Los Boldos, Hueicolla Cut, and Hueicolla Cut, all on the western slope of the Coastal Range, had the fewest seedlings. These stands were significantly different from La Montaña and Llancahue.

TABLE 4

Seedling densities (number ha ${ }^{-1}$ ) of canopy species in the seven stands studied in Valdivian forests Densidad de plántulas (número ha-1) de especies del dosel en los siete rodales estudiados

\begin{tabular}{|c|c|c|c|c|c|c|c|c|}
\hline \multirow[t]{2}{*}{ Species } & class $(\mathrm{cm})$ & \multicolumn{7}{|c|}{$\operatorname{Stand}^{\mathrm{a}}$} \\
\hline & & LL & $\mathrm{LU}$ & $\mathrm{LC}$ & LM & LB & $\mathrm{HU}$ & $\mathrm{HC}$ \\
\hline \multirow[t]{4}{*}{ Gevuina avellana } & $5-<50$ & 52 & 0 & 260 & 624 & 1,406 & 62 & 0 \\
\hline & $50-<100$ & 0 & 0 & 52 & 156 & 312 & 0 & 62 \\
\hline & $100-<200$ & 52 & 0 & 156 & 260 & 678 & 126 & 0 \\
\hline & Saplings & 156 & 0 & 156 & 260 & 416 & 188 & 124 \\
\hline \multirow[t]{4}{*}{ Drimys winteri } & $5-<50$ & 260 & 312 & 624 & 0 & 0 & 250 & 1,250 \\
\hline & $50-<100$ & 0 & 156 & 156 & 0 & 0 & 125 & 376 \\
\hline & $100-<200$ & 468 & 416 & 52 & 0 & 0 & 250 & 438 \\
\hline & Saplings & 208 & 52 & 0 & 0 & 0 & 62 & 62 \\
\hline \multirow[t]{4}{*}{ Podocarpus } & $5-<50$ & 208 & 0 & 0 & 0 & 1,352 & 62 & 626 \\
\hline & $50-<100$ & 52 & 0 & 0 & 0 & 104 & 62 & 0 \\
\hline & $100-<200$ & 0 & 0 & 52 & 0 & 0 & 0 & 252 \\
\hline & Saplings & 156 & 0 & 0 & 0 & 104 & 0 & 0 \\
\hline \multirow[t]{4}{*}{ Aextoxicon punctatum } & $5-<50$ & $5,000 \mathrm{~b}$ & 208 & 0 & $18,698 \mathrm{a}$ & $1,406 \mathrm{~b}$ & $313 b$ & $313 b$ \\
\hline & $50-<100$ & $990 \mathrm{ab}$ & 0 & 0 & $1,666 \mathrm{a}$ & 313 & Ob & $63 b$ \\
\hline & $100-<200$ & $468 \mathrm{ab}$ & 0 & 0 & 990a & $364 b$ & $62 b$ & $0 \mathrm{~b}$ \\
\hline & Saplings & $208 \mathrm{a}$ & 0 & 0 & $104 \mathrm{ab}$ & $52 \mathrm{ab}$ & ob & $0 \mathrm{~b}$ \\
\hline \multirow[t]{4}{*}{ Laurelia philippiana } & $5-<50$ & $2,708 \mathrm{ab}$ & $5,104 \mathrm{a}$ & $5,208 \mathrm{a}$ & $1,563 \mathrm{ab}$ & 313 & $500 \mathrm{~b}$ & $938 b$ \\
\hline & $50-<100$ & $1,198 \mathrm{ab}$ & $1,250 \mathrm{ab}$ & $2,032 \mathrm{a}$ & $678 b$ & $104 b$ & $250 \mathrm{~b}$ & $438 b$ \\
\hline & $100-<200$ & $1,042 \mathrm{ab}$ & $989 a b$ & $1,510 \mathrm{a}$ & $834 \mathrm{ab}$ & $208 b$ & $62 b$ & $188 \mathrm{~b}$ \\
\hline & Saplings & $1,615 \mathrm{a}$ & $781 \mathrm{~b}$ & $260 b c$ & $417 b c$ & $156 c$ & $125 \mathrm{c}$ & $188 \mathrm{c}$ \\
\hline \multirow[t]{4}{*}{ Eucryphia cordifolia } & $5-<50$ & $5,104 \mathrm{a}$ & $886 \mathrm{~b}$ & $1,667 \mathrm{~b}$ & $208 b$ & $1,142 b$ & $500 \mathrm{~b}$ & $375 b$ \\
\hline & $50-<100$ & $1,406 \mathrm{a}$ & $365 b$ & $782 \mathrm{ab}$ & $208 b$ & $260 b$ & $500 \mathrm{ab}$ & $188 \mathrm{~b}$ \\
\hline & $100-<200$ & $1,042 \mathrm{a}$ & $1,042 \mathrm{a}$ & $572 \mathrm{ab}$ & $208 \mathrm{ab}$ & $468 \mathrm{ab}$ & $62 b$ & $500 \mathrm{ab}$ \\
\hline & Saplings & 313 & $208 \mathrm{a}$ & $104 \mathrm{a}$ & $52 \mathrm{a}$ & $312 \mathrm{a}$ & $126 a$ & $438 \mathrm{a}$ \\
\hline \multirow[t]{5}{*}{ Total $^{b}$} & $5-<50$ & $13,332 b$ & $7,031 \mathrm{bc}$ & $9,010 \mathrm{bc}$ & $24,583 \mathrm{a}$ & $5,990 \mathrm{bc}$ & $1,688 \mathrm{c}$ & $3,500 \mathrm{c}$ \\
\hline & $50-<100$ & $3,646 \mathrm{a}$ & $2,292 \mathrm{abc}$ & $3,073 \mathrm{ab}$ & $3,125 \mathrm{ab}$ & $1,198 \mathrm{bc}$ & $938 \mathrm{c}$ & $1,250 \mathrm{bc}$ \\
\hline & $100-<200$ & $3,073 \mathrm{ab}$ & $3,385 \mathrm{a}$ & $2,396 \mathrm{ab}$ & $3,594 \mathrm{a}$ & $1,771 \mathrm{ab}$ & $563 b$ & $1,438 \mathrm{ab}$ \\
\hline & $5-<200$ & $20,052 b$ & $12,708 \mathrm{bcd}$ & $14,479 \mathrm{bc}$ & $3,1302 \mathrm{a}$ & $8,958 \mathrm{~cd}$ & $3,188 \mathrm{~d}$ & $6,625 \mathrm{~cd}$ \\
\hline & Saplings & $2,656 \mathrm{a}$ & $1,042 b$ & $521 \mathrm{~b}$ & $1,815 \mathrm{ab}$ & $1,042 b$ & $500 \mathrm{~b}$ & $938 b$ \\
\hline
\end{tabular}

(a) LL = Llancahue; LU = Llancacura Uncut; LC = Llancacura Cut; LM = La Montaña; LB = Los Boldos; HU = Hueicolla Uncut; $\mathrm{HC}=$ Hueicolla Cut;

(b) Different letters within each row following total numbers of seedlings or saplings denote statistically significant differences in numbers between stands $(\mu=0.05)$ 
The high seedling density at La Montaña was due to the abundance of $A$. punctatum in the $5-<50 \mathrm{~cm}$ class, with numbers significantly greater than all other stands. Seedlings at Llancahue were more evenly distributed among A. punctatum, E. cordifolia, and L. philippiana (Table 4). E. cordifolia was most abundant at Llancahue. At Llancacura, L. philippiana was the most abundant species, and accounted for $68 \%$ (Llancacura Uncut) and $60 \%$ (Llancacura Cut) of all seedlings.

The density of saplings was also greater in stands on the eastern slope, with significantly greater numbers at Llancahue than elsewhere $\left(2,656\right.$ versus an average of $<1,000$ saplings ha ${ }^{-1}$ for the other stands), except for La Montaña. Although Hueicolla Uncut and Hueicolla Cut had only limited numbers of seedlings and saplings of upper canopy species, they had the lowest ratio of numbers in the $5-<50 \mathrm{~cm}$ class to those of sapling size, suggesting a better rate of survival for the few seedlings that became established. By stand, these ratios were: Hueicolla Uncut $=3.4$, Hueicolla Cut $=4.3$, Llancahue $=5.0$, Los Boldos $=5.8$, Llancacura Uncut $=6.3$, Llancacura Cut $=$ 17.3, La Montaña $=22.1$.

\section{TABLE 5}

Seedling density (number ha-1) of subcanopy tree species in the seven stands

Densidad de plántulas (número ha $^{-1}$ ) de especies arbóreas del dosel inferior

\begin{tabular}{|c|c|c|c|c|c|c|c|c|}
\hline \multirow[t]{2}{*}{ Species } & Height class $(\mathrm{cm})$ & \multicolumn{7}{|c|}{$\operatorname{Stand}^{\mathrm{a}}$} \\
\hline & & LL & LU & $\mathrm{LC}$ & LM & LB & $\mathrm{HU}$ & $\mathrm{HC}$ \\
\hline \multicolumn{9}{|l|}{ Raphythamnus } \\
\hline \multirow[t]{4}{*}{ spinosum } & $5-<50$ & 730 & 0 & 416 & 2,916 & 468 & 500 & 62 \\
\hline & $50-<100$ & 104 & 0 & 0 & 572 & 0 & 0 & 62 \\
\hline & $100-<200$ & 260 & 0 & 0 & 678 & 52 & 62 & 62 \\
\hline & Saplings & 312 & 0 & 0 & 208 & 0 & 0 & 0 \\
\hline \multirow[t]{4}{*}{ Aristotelia chilensis } & $5-<50$ & 0 & 0 & 938 & 2,708 & 782 & 0 & 0 \\
\hline & $50-<100$ & 0 & 0 & 104 & 364 & 52 & 0 & 0 \\
\hline & $100-<200$ & 0 & 0 & 104 & 1,302 & 156 & 0 & 0 \\
\hline & Saplings & 0 & 0 & 52 & 678 & 416 & 0 & 0 \\
\hline \multirow[t]{4}{*}{ Myrtaceas } & $5-<50$ & 8,228 & 6,614 & 14,634 & 468 & 3,542 & 12,000 & 22,000 \\
\hline & $50-<100$ & 2,188 & 1,406 & 1,198 & 208 & 1,302 & 1,688 & 4,126 \\
\hline & $100-<200$ & 2,188 & 2,708 & 782 & 156 & 1,406 & 1,376 & 2,938 \\
\hline & Saplings & 3,594 & 1,980 & 260 & 52 & 572 & 500 & 1,062 \\
\hline \multirow[t]{4}{*}{ Lomatia ferruginea } & $5-<50$ & 312 & 1,042 & 1,146 & 0 & 2,188 & 812 & 4,688 \\
\hline & $50-<100$ & 208 & 312 & 520 & 0 & 624 & 750 & 1,188 \\
\hline & $100-<200$ & 156 & 730 & 572 & 0 & 624 & 562 & 1,376 \\
\hline & Saplings & 0 & 208 & 105 & 0 & 312 & 376 & 938 \\
\hline \multicolumn{9}{|l|}{ Dasyphyllum } \\
\hline \multirow[t]{4}{*}{ diacanthoides } & $5-<50$ & 416 & 572 & 624 & 0 & 52 & 1,124 & 312 \\
\hline & $50-<100$ & 260 & 156 & 468 & 0 & 0 & 126 & 62 \\
\hline & $100-<200$ & 104 & 208 & 364 & 0 & 0 & 62 & 126 \\
\hline & Saplings & 104 & 208 & 104 & 0 & 0 & 126 & 188 \\
\hline \multirow[t]{5}{*}{ Total $^{b}$} & $5-<50$ & $9,844 \mathrm{bcd}$ & $8,229 \mathrm{~cd}$ & $18,488 \mathrm{ab}$ & $3,490 \mathrm{c}$ & $7,240 \mathrm{~cd}$ & $14,500 \mathrm{bc}$ & $27,126 a$ \\
\hline & $50-<100$ & $2,760 \mathrm{~b}$ & $1,875 b c$ & $2,552 b c$ & $885 c$ & $2,032 b c$ & $2,563 \mathrm{bc}$ & $5,500 \mathrm{a}$ \\
\hline & $100-<200$ & $2,708 \mathrm{bc}$ & $33,698 \mathrm{ab}$ & $1,927 \mathrm{~cd}$ & $938 \mathrm{~d}$ & $2,240 \mathrm{~cd}$ & $2,126 \mathrm{~cd}$ & $4,563 \mathrm{a}$ \\
\hline & $5-<200$ & $15,312 \mathrm{bcd}$ & $13,802 \mathrm{bcd}$ & $22,969 b$ & $5,313 d$ & $11,510 \mathrm{~cd}$ & $19,188 b c$ & $37,188 \mathrm{a}$ \\
\hline & Saplings & $4,010 \mathrm{a}$ & $2500 \mathrm{~b}$ & $938 \mathrm{~cd}$ & $312 d$ & $1,302 \mathrm{bcd}$ & $1,000 \mathrm{~cd}$ & $2,250 \mathrm{bc}$ \\
\hline
\end{tabular}

(a) LL = Llancahue; LU = Llancacura Uncut; LC = Llancacura Cut; LM = La Montana; LB = Los Boldos; HU = Hueicolla Uncut; $\mathrm{HC}=$ Hueicolla Cut;

(b) Different letters within each row following total numbers of seedlings or saplings denote statistically significant differences in numbers between stands $(\mu=0.05)$ 
Seedling density among subcanopy species

Subcanopy tree species included $R$. spinosum, Aristotelia chilensis, L. ferruginea, species of the Myrtaceae family (mainly A. luma, Amomyrstus meli, and Myrceugenia planipes), and Dasyphyllum diacanthoides. The first three are small trees that reach a position below the main canopy, but at Hueicolla Uncut and Hueicolla Cut, some individuals of the Myrtaceae species had grown into the main canopy. A. chilensis is a short-lived shadeintolerant species that we found only in the most recently cut stands. Some $D$. diacanthoides also were in the main canopy at Hueicolla Uncut, Hueicolla Cut, Llancacura Uncut, and Llancacura Cut.

Seedlings of the Myrtaceae species were the most abundant subcanopy species, except at La Montaña. There, $R$. spinosum and A. chilensis were the dominant species among seedlings (Table 6). The greatest numbers of subcanopy seedlings were in the $5-<50 \mathrm{~cm}$ class.

Hueicolla Cut had the greatest number of subcanopy seedlings $(27,126)$, and this differed significantly from all other stands for each of the height classes. In fact, Hueicolla Cut differed significantly with all other stands, with two-thirds to three times more seedlings than the stands with intermediate numbers (Hueicolla Uncut, Llancacura Cut, Llancacura Uncut, and Llancahue). La Montaña $(9,686)$ and Los Boldos $(11,510)$ had the fewest seedlings $\mathrm{ha}^{-1}$ of subcanopy species. For saplings, Llancahue ranked first (4,010 saplings $\mathrm{ha}^{-1}$ ), with significantly more than all other stands (Table 6).

\section{Regeneration models}

The regeneration models developed from these data had $\mathrm{R}^{2}$ values from 0.344 to 0.828 . All were highly significant, with P-values $<0.004$ (Table 6). The most significant models were the ones for all canopy species, and for $A$. punctatum. The cover of Chusquea spp. was a significant explanatory variable in all models for all plots, for IR plots in the case of $L$. philippiana, and for $\mathrm{S}$ plots in the case of $A$. punctatum. Another understory species, $L$.

TABLE 6

Regression models for seedling density $(5-200 \mathrm{~cm}$ tall ha-1). In multiple regression models, variables with a greater significance are given first

Modelos de regresión para densidad de plántulas (5-200 $\left.\mathrm{cm}_{\text {de altura ha }}{ }^{-1}\right)$. En modelos de regresión múltiple primero se entregan las variables de mayor significancia

\begin{tabular}{llrrr}
\hline Plot $\quad$ Model & $\mathrm{R}^{2}$ & MSE & P-value \\
\hline All canopy species & & & \\
All $\quad \log (\operatorname{Reg})=5.07944-0.0005402 * C 200^{2}-0.03017 * \mathrm{QSD}+0.04401 * \mathrm{CI}$ & 0.615 & 0.0674 & $<0.0001$ \\
IR $\quad \log (\operatorname{Reg})=4.08345-0.0002833^{*} \mathrm{C}^{2}$ & 0.806 & 0.0261 & $<0.0001$ \\
S & $\log (\operatorname{Reg})=4.41035-0.02403 * \mathrm{Lq} 50-0.00018376^{*} \mathrm{C}^{2}$ & 0.632 & 0.0420 & 0.0002
\end{tabular}

Laureliopsis philippiana

$\begin{array}{ll}\text { All } & \text { Reg }=2962.32+652.26 * \mathrm{CI}-116.411 * \mathrm{C} 200 \\ \text { IR } & \text { Reg }=7,408.8-1,037.39 * \sqrt{C} \\ \text { S } & \text { Reg }=3021.15+67.094 * \mathrm{CI}^{2}\end{array}$

Aextoxicon punctatum

\begin{tabular}{llrrr} 
All & $\log (\mathrm{Reg})=3.75071-0.0177 * \mathrm{C} 200^{2}$ & 0.561 & 0.5608 & $<0.0001$ \\
IR & $\log (\mathrm{Reg})=4.19144-0.35364 * \mathrm{CI}^{2}$ & 0.707 & 0.32585 & 0.0012 \\
S & $\log (\mathrm{Reg})=3.92972-0.00252 * \mathrm{C} 200^{2}$ & 0.828 & 0.2324 & $<0.0001$ \\
\hline
\end{tabular}

Reg = number of seedlings 5-200 ha-1; CI = Crown Index; LC = crown cover $\left(\mathrm{m}^{2} \mathrm{ha}^{-1}\right)$ of large trees $(>45 \mathrm{~cm}) ; \mathrm{QSD}=$ quadratic stand diameter $(\mathrm{cm}) ; \mathrm{C}=$ cover $(\%)$ of Chusquea sp.; C 200: cover $(\%)$ of Chusquea $\mathrm{sp} ., \geq 200 \mathrm{~cm}$ tall; Lq50 = cover $(\%)$ of Lophosoria quadripinnata $\geq 50 \mathrm{~cm}$ tall

$\begin{array}{lrl}0.344 & 18870857 & 0.0004 \\ 0.486 & 110607979 & 0.0039 \\ 0.485 & 11996474 & 0.0006\end{array}$


quadripinnata, was also negatively related to seedling density in one model (S plots for all canopy species). For both species, in many cases the tall cover in L. quadripinnata (> 50 $\mathrm{cm})$ and Chusquea spp. (> $200 \mathrm{~cm}$ ) had a more significant effect than the cover with all height classes combined.

Basal area and canopy cover were not significant explanatory variables in any model. Among structural variables, QSD was negatively related to seedling density in the model for all plots and canopy species. CI was positively related to seedling density in the models for all plots, for all canopy species and $L$. philippiana, and for $S$ plots and $L$. philippiana. It was negatively related to $A$. punctatum in S plots.

Models that were fitted for plots according to their structure (as reflected by proportions of large, medium, and small trees) had, in all cases, greater $\mathrm{R}^{2}$ values than those without this separation. Except for the model for $\mathrm{S}$ plots based on all canopy species, increases in $\mathrm{R}^{2}$ values were from 14 to $26 \%$.

\section{DISCUSSION}

\section{Effects of diameter structure over seedling densities}

Although all plots were dominated by similar species and had a multistoried canopy, those with S or SL structures had greater numbers of seedlings. Stands with an IR structure had intermediate seedling densities (Table 7). Stands with diameter distributions having few large trees, medium numbers of intermediatesized ones, and a discontinuous upper canopy layer apparently favoured the development of advance regeneration. By contrast, stands with a dense middle canopy layer had the lowest density of regeneration, possibly due to heavy shading from the many intermediate-sized trees of medium heights. For L. philippiana, seedling density was greatest among plots having similar numbers of small and large trees (SL plots, Table 7), compared to plots dominated by small trees or a combination of small and medium trees. This suggests that $L$. philippiana regenerates best in plots that have a limited middle canopy layer, and important proportions of large trees. In stands with an important degree of middle story development (i.e., IR and SM plots), seedling densities were lower (Table 7). As with L. philippiana, seedling density of $A$. punctatum was lower in IR and SM plots (Table 7).

\section{Effects of understory species over seedling density}

Chusquea spp. was the most influential understory species affecting seedling density. These species characterize the understory component of Chilean temperate forests located from 37 to $43^{\circ} \mathrm{S}$. Their negative effects on regeneration success have been reported extensively for other temperate forests within Chile, and elsewhere (Veblen 1992, Donoso

TABLE 7

Average and standard deviation of seedling densities of all canopy species, L. philippiana, and A. punctatum in plots with differing proportions of trees in broad diameter classes, according to Fig. 1

El promedio de desviación normal de densidades de plántulas de todas las especies de dosel, L. philippiana y A punctatum en las parcelas con diferentes proporciones de árboles en las clases del diámetro anchas, según Fig. 1

\begin{tabular}{|c|c|c|c|c|}
\hline \multirow[t]{3}{*}{ Species } & \multicolumn{4}{|c|}{ Plot structure } \\
\hline & \multicolumn{3}{|c|}{ S-dominated plots } & \multirow{2}{*}{$\begin{array}{l}\text { IR plots } \\
\text { IR }\end{array}$} \\
\hline & $S$ & SM & SL & \\
\hline All canopy species & $23,781 \pm 11,774 \mathrm{a}$ & $7,578 \pm 3,630 \mathrm{bc}$ & $17,396 \pm 10,695 \mathrm{ab}$ & $8,292 \pm 5,218 \mathrm{ab}$ \\
\hline Laurelia philippiana & $4,063 \pm 3,340 \mathrm{ab}$ & $2,109 \pm 299 b$ & $7,396 \pm 6,987 \mathrm{a}$ & $3,167 \pm 4,031 \mathrm{ab}$ \\
\hline Aextoxicon punctatum & $14,281 \pm 13,356 a$ & $1,355 \pm 2,080 \mathrm{~b}$ & $6,771 \pm 7,410 \mathrm{~b}$ & $1,421 \pm 1,656 b$ \\
\hline
\end{tabular}

Note: different letters within each row following total numbers of seedlings denote statistically significant differences in numbers $(\mathrm{m}=0.05)$ 
1993, González et al. 2002; see also references in these sources). Chusquea quila, a shadeintolerant species that grows at relatively low elevations, will prevent or delay regeneration, particularly in open sites (e.g., Donoso 1989, González et al. 2002). C. machrostachya is more tolerant to shade (M. González, personal communication) and can survive under relatively dense closed-canopy forests, as evidenced in this study. Such findings suggest that in lower elevation stands having $C$. quila and with basal areas similar to those sampled in this study, Chusquea should not impede the development of desirable regeneration.

The fern L. quadripinnata had a relatively important effect on tree seedling densities. In fact, tall cover $(>50 \mathrm{~cm})$ of this species was a significant explanatory variable in one of the regeneration models. Similarly, the tall cover of Chusquea spp. (> $200 \mathrm{~cm})$, rather than total cover of that species, was a significant explanatory variable of tree seedling density within several regeneration models.

Available information suggests that interference may be caused by rhizomatous ferns (e.g., reported in North America by Horsley 1993, and in New Zealand by Beveridge 1973), by Chusquea spp. (Veblen 1992, Donoso 1993, Lusk 1995, Lusk 1996, González et al. 2002; see also references in these sources), or by a generally dense cover of other tall understory vegetation (Lorimer et al. 1994, Clinton 2003). Under appropriate conditions, bamboos and ferns rapidly dominate the understory, preempt resources, and create an unfavourable understory microclimate for other species (Clinton 2003), including trees. This seems the case among our sample stands having the highest cover of L. quadripinnata and Chusquea spp., which were also the stands with the lowest number of vascular plants and at an elevation $>500 \mathrm{~m}$ (C. machrostachya at Hueicolla Uncut, Hueicolla Cut, and Los Boldos, and $L$. quadripinnata at Llancacura Uncut and Llancacura Cut). The two lower elevation stands (Llancahue and La Montaña) seem to presently have better regeneration of canopy species. Based on the diameter distributions in these stands, with the interspersion of trees having different diameters and heights (Donoso 2002), this might also have been the situation in the past.
Effects of tree dominance and vertical structure over seedling density

Basal area and canopy cover were used as measures of dominance in this study. In the past, canopy cover has been regarded as a more reliable measure of dominance, because basal area continues to increase at a linear rate even after crown area has approached an asymptote (Cole 1991). Both high basal area (e.g., Leak \& Graber 1976, Crow \& Metzger 1987) and a dense canopy cover (Clark et al. 1999) reportedly have negative effects on regeneration success. Yet those variables did not explain differences in seedling density in our study. Similarly, Berg \& Van Lear (2004) also found little relationship between these factors and regeneration density in other temperate hardwood forests.

We used crown index (CI) and quadratic stand diameter (QSD) as surrogates for stand structure, and entered them as variables in the regression models. QSD was only significant in the model for all plots and all species, and had a negative relationship to seedling density. CI was a significant explanatory variable in several models. While all the sample plots had high vertical structure (sensu Brokaw \& Lent 2001), CI reflected the degree of balance among the different tree strata within a plot.

For all canopy species, CI was positively related to seedling density when we lumped all plots. When we separated the plots into Sdominated or IR plots, CI was not a significant explanatory variable. The positive relationship of CI and seedling density for L. philippiana in the model for combined plots was very weak (Table 6). The relationship greatly improved when only S-dominated plots were considered. For these plots CI was the only explanatory variable for seedling density. For plots having more balanced numbers of trees across the diameter classes (IR plots) we observed no relationship between seedling density and CI for L. philippiana. Understory cover rather than vertical structure seems to more profoundly affect tree seedling density in those cases (Table 6).

With A. punctatum we found no relationship between seedling density and CI for all plots combined, or among S-dominated plots. For the latter condition, density was negatively affected by cover of Chusquea spp. Density was 
sensitive to CI only within IR plots, and seedling numbers declined with higher CI values (i.e., plots with a relative high proportion of crown area among large trees).

Although both species seem sensitive to shade by Chusquea spp., A. punctatum seems more tolerant than L. philippiana to conditions beneath a continuous canopy in stands having more balanced numbers of trees across the diameter classes (IR plots). Laurelia philippiana appears especially sensitive to shade cast by a middle canopy layer and regenerates better beneath stands with a broken vertical structure. Usually both species have been classified as being very shade tolerant (Donoso 1993, Figueroa \& Lusk 2001). Yet, in addition to the present findings that relate the regeneration of these species according to cover and vertical structure, little has been reported on their habitat choices in regions where both species grow and coexist. For regions where $A$. punctatum does not grow, it has been reported that for L. philippiana numbers of seedlings established on logs are similar or greater than those established on litter (Lusk 1995, Christie \& Armesto 2003). On the contrary, in low-land forests of Valdivia, Neumann (2001) reported that both $L$. philippiana and A. punctatum had a small proportion of seedlings growing on $\log s$, although the former had a greater proportion (18 versus $3 \%$ ). Thus, in addition to possible microsite preferences, these two species (widely known as shade tolerant) also seem to respond differently to light availability. Analyses of both variables combined could provide a better explanation for plant recruitment, especially considering that regeneration on coarse woody debris may help these tree species to escape understory species interference.

This observational study revealed a wide range of seedling densities among stands of the evergreen forest type in the coastal range of Chile. Findings indicate that within the levels of basal area studied (only one plot having $<40$ $\mathrm{m}^{2} \mathrm{ha}^{-1}$ ), understory cover of Chusquea spp. and L. quadripinnata, and stand vertical structure, were the best indicators of seedling density for canopy species in general, as well as that of the two major shade-tolerant species. Neither the degree of canopy cover nor the total stand basal area, alone or in combination, appeared to significantly affect seedling density in stands of this forest community type. Silvicultural experiments that test alternate levels of residual basal area might identify thresholds where those two stand attributes have greater effects on the establishment and development of advance regeneration, and where less shade-tolerant species like $C$. quila begin to importantly interfere with seedling establishment within low elevation stands.

\section{ACKNOWLEDGEMENTS}

We thank J.C. Aravena, J. Caldentey and M. González, and two anonymous referees for reviews to this manuscript. We are also thankful to Forestal Tornagaleones and Forestal Llancacura, who gave us permission and logistic support to sample stands within their properties. This study was partially supported by the CONAF/UACH project "Ecology and Silviculture of the Native Forests of the Xth Region".

\section{LITERATURE CITED}

ARAVENA, MC CARMONA, CA PÉREZ \& JJ ARMESTO (2002) Changes in tree species richness, stand structure and soil properties in a successional chronosequence in northern Chiloé Island, Chile. Revista Chilena de Historia Natural 75: 339-360.

ARMESTO JJ \& ER FUENTES (1988) Tree species regeneration in a mid-elevation, temperate rainforest in Isla de Chiloé, Chile. Vegetation 74: 151-159.

BARNES BV, DR ZAK, SR DENTON \& SH SPURR (1998) Forest ecology. Fourth Edition. John Wiley \& Sons, New York, New York, USA. 774 pp.

BERG EC \& DH VAN LEAR (2004) Yellow-poplar and oak seedling density responses to wind-generated gaps. In: Connor CF (ed) Proceedings of the $12^{\text {th }}$ biennial southern silvicultural research conference: 254-259. USDA Forest Service, General Technical Report SRS-71, Ashville, North Carolina, USA.

BEVERIDGE AE (1973) Regeneration of podocarps in a central North Island forest. New Zealand Journal of Forestry 18: 23-35.

BROKAW NV \& RA LENT (1999) Vertical structure. In: Hunter M (ed) Maintaining biodiversity in forest ecosystems: 373-399. Cambridge University Press, New York, New York, USA.

CHRISTIE D \& J ARMESTO (2003) Regeneration microsites and tree species coexistence in temperate rain forests of Chiloé Island, Chile. Journal of Ecology 91: 776-784.

CIREN (1999) Estudio agrológico de la Provincia de Valdivia-X Región. Descripciones de suelos. Materiales y Símbolos. Santiago, Chile. 178 pp. 
CLARK JS, B BECKAGE, P CAMILL, B CLEVELAND, J HIILERISLAMBER, J LICHTER, J MCLACHLAN, J MOHAN \& P WYCKOFF (1999) Interpreting recruitment limitations in forests. American Journal of Botany 68: 1-16.

CLINTON BD (2003) Light, temperature, and soil moisture responses to elevation, evergreen understory, and small canopy gaps in the southern Appalachians. Forest Ecology and Management 186: 243-255

COLE WG (1991) Prediction of tree growth and gap closure rates after selective cutting in secondgrowth northern hardwood forests. Ph.D. Thesis, University of Wisconsin, Madison, Wisconsin, USA. $141 \mathrm{pp}$.

COTTAM G \& JT CURTIS (1956) The use of distance measures in phytosociological sampling. Ecology 37: 451-460.

CROW TR \& FT METZGER (1987) Regeneration under selection cutting. In: Nyland RD (ed) Managing northern hardwoods: 81-94. State University of New York, College of Environmental Science and Forestry, Syracuse, New York, Faculty of Forestry Miscellaneous Publication 13 (ESF 87-002). SAF Publication $\mathrm{N}^{\circ}$ 87-03.

DONOSO C (1981) Tipos forestales de los bosques nativos de Chile. Documento de trabajo 38. Investigación y Desarrollo Forestal (CONAF/PNUD-FAO) (Publicación FAO Chile), Santiago, Chile. 128 pp.

DONOSO C (1989) Regeneración y crecimiento en el tipo forestal siempreverde costero y andino tras distintos tratamientos silviculturales. Bosque (Chile) 10: 69-83.

DONOSO C (1993) Estructura, variación y dinámica de bosques templados de Chile y Argentina. Ecología Forestal. Editorial Universitaria, Santiago, Chile. $484 \mathrm{pp}$.

DONOSO C, B ESCOBAR \& J URRUTIA (1985) Estructura y estrategias regenerativas de un bosque virgen de ulmo (Eucryphia cordifolia Cav.)-Tepa (Laurelia philippiana Phil.) Looser en Chiloé, Chile. Revista Chilena de Historia Natural 58: 171-186.

DONOSO P (2002) Structure and growth in coastal evergreen forests as the bases for uneven-aged silviculture in Chile. Ph.D. Thesis, State University of New York, College of Environmental Science and Forestry, Syracuse, New York, USA. 256 pp.

FIGUEROA JA \& CH LUSK (2001) Germination requirements and seedling shade tolerance are not correlated in a Chilean temperate rainforest. New Phytologist 152: 483-489.

GONZÁLEZ M, TT VEBLEN, C DONOSO \& L VALERIA (2002) Tree regeneration responses in a lowland Nothofagus-dominated forest alter bamboo dieback in south-central Chile. Plant Ecology 161: 59-73.

HORSLEY SB (1993) Mechanisms of interference between hay-scented fern and black cherry. Canadian Journal of Forest Research 23: 2059-2069.

LEAK WB \& RE GRABER (1976) Seedling input, death and growth in uneven-aged northern hardwoods. Canadian Journal of Forest Research 6: 368-374.

LORIMER CG, JW CHAPMAN \& WD LAMBERT (1994) Tall understory vegetation as a factor in the poor development of oak seedlings beneath mature stands. Journal of Ecology 82: 227-237.

LUSK CH (1995) Seed size, establishment stands and species coexistence in a Chilean rainforest. Journal of Vegetation Science 6: 249-256.

LUSK CH (1996) Stand dynamics of the shade-tolerant conifers Podocarpus nubigena and Saxegothaea conspicua in Chilean temperate rain forest. Journal of Vegetation Science 7: 549-558.

NEUMANN RF (2001) Análisis de la estructura y dinámica de un bosque remanente original de roble-laurellingue en el fundo San Julián, Comuna de Panguipulli, X Región. Tesis Ingeniería Forestal, Universidad Austral de Chile, Valdivia, Chile. 103 pp.

NYLAND RD (2002) Silviculture: concepts and applications. Second edition. McGraw-Hill, New York, New York, USA. 704 pp.

OLIVER CD \& BC LARSON (1996) Forest stand dynamics. Update edition. John Wiley and Sons, Inc., New York, New York, USA. 520 pp.

PEZOA L (2003) Recopilación y análisis de la variación de las temperaturas (período 1965-2001) y las precipitaciones (período 1931-2001) a partir de la información de estaciones meteorológicas de Chile entre los 33 y $53^{\circ}$ de latitud Sur. Tesis Ingeniería Forestal, Universidad Austral de Chile, Valdivia, Chile. 99 pp.

SAS INSTITUTE (2001) SAS/STAT user's guide. Release 8.1. SAS Institute, Inc., Cary, North Carolina, USA.

SCHLATTER J, V GERDING \& J ADRIAZOLA (1995). Sistema de ordenamiento de la tierra. Herramienta para la planificación forestal aplicado a la X Región. Serie Técnica, Facultad de Ciencias Forestales, Universidad Austral de Chile, Valdivia, Chile. 93 pp.

SCHLATTER J, V GERDING \& J ADRIAZOLA (1997) Sistema de ordenamiento de la tierra. Herramienta para la planificación forestal aplicada a las Regiones VII, VIII y IX. Serie Técnica, Facultad de Ciencias Forestales, Universidad Austral de Chile, Valdivia, Chile. $91 \mathrm{pp}$.

SFFC (Société Forestière de Franche-Comté) (2000) Typologie des pepleuments feuillus irréguliers de Franche-Comté. Thise, France. 32 pp.

SZEWCZYK J \& J SZWAGRZYK (1996) Tree regeneration on rotten wood and on soil in oldgrowth stand. Vegetatio 122: 37-46.

VAN PELT R \& JF FRANKLIN (2000) Influence of canopy structure on the understory environment in tall, old-growth, conifer forests. Canadian Journal of Forestry Research 30: 1231-1245.

VEBLEN TT (1992) Regeneration dynamics. In: GlennLewin C, RK Peet \& TT Veblen (eds) Plant succession: theory and prediction: 53-187. Chapman and Hall, London, United Kingdom.

VEBLEN TT, DH ASHTON \& F SCHLEGEL (1979) Tree regeneration strategies in a lowland Nothofagusdominated forest in south-central Chile. Journal of Biogeography 6: 329-340.

VEBLEN TT, C DONOSO, F SCHLEGEL \& B ESCOBAR (1981) Forest dynamics in south-central Chile. Journal of Biogeography 8: 211-247. 